Revista do SELL

v. 6 , no. 2

ISSN: $1983-3873$

\title{
GUINÉ-BISSAU: A LITERATURA SOB O VIÉS DA REVOLUÇÃO E DA POESIA
}

\author{
GUINEA-BISSAU: LITERATURE UNDER THE BIAS OF THE REVOLUTION AND \\ POETRY
}

\author{
Rosa Alda Souza de Oliveira \\ Universidade de Brasília
}

\begin{abstract}
RESUMO: O presente trabalho propõe uma leitura da formação literária da Guiné-Bissau, sob a perspectiva da poesia e da revolução, levando em consideração os poemas da antologia Mantenhas para quem luta publicada em 1977. A proposta é a de perceber como o sujeito lírico apresenta, esteticamente, o espírito revolucionário guineense que culminou não apenas na aclamada independência, mas também na formação de um esboço literário do país. Assim, pelo viés da poesia, busca-se mostrar como esta, enquanto espaço privilegiado da utopia e da crítica mostra-se capaz de representar um determinado grupo social e um determinado tempo histórico. Nesse sentido, literatura e história além de espaços de representação, se tornam também espaços de reflexão da crítica sobre a arte e a sociedade.
\end{abstract}

PALAVRAS-CHAVE: Literatura; Revolução; Antologia; Guiné-Bissau.

ABSTRACT: The presente work intend to a reading of the literary formation of Ginea-Bissau, from the perspective of poetry and the revolution, taking into account the poems anthology Mantenhas para quem luta, published in 1977. The proposal is to understand how the lirycal subject presents, aesthetically, the revolutionary mindset of guinean that did not end only in the acclaimed independence, but also an outline of literary formation of the country. Therefore, through the poetry, purpose show how it, as a privileged utopian place and of criticism is able to represent a particular social group and a particular historical time. In this sense, literature and history are more than spaces of representation, become spaces of reflection of criticism about art and society.

KEYWORDS: Literature; Revolution; Anthology; Guinea-Bissau.

Este trabalho desempenha o papel de fazer uma leitura do conjunto de poemas que compõem a antologia Mantenhas para quem luta (1977) pelas vias da revolução (agitação subversiva), tendo como base a formulação estética presente na produção dos escritores guineenses. Dessa forma, a poesia aparece aqui a partir da aliança firmada entre as camadas particulares e sociais e as vertentes artísticas. Com isso foi possível contemplar um dos aspectos mais relevantes desta compilação aqui cotejada: o diálogo rigoroso entre autor, arte e sociedade, tão bem representado pelos poetas ao proporem revelar os anseios do homem guineense durante a luta pela libertação e no pósindependência.

O objetivo aqui proposto não é esboçar um mapeamento sociológico, mas sim observar de que maneira uma sociedade que foi subjugadas historicamente, como é o caso da Guiné-Bissau, se manifesta nos textos da antologia e, consequentemente dão o 


\section{Revista do SELL}

v. 6 , no. 2

ISSN: $1983-3873$

mote que estimula a própria criação literária. Ademais, vale ressaltar que não se intenta aqui contar a história como conjuntura de produção de texto, mas sim que ela é o próprio texto. "Os elementos de ordem social serão filtrados através de uma concepção estética e trazidos ao nível da fatura, para entender a singularidade e a autonomia da obra" (CANDIDO, 1965, p. 16-7).É assim que se dá a poesia guineense, inserida nesse campo que apreende a realidade e a transforma em outra, que mesmo idealizada se faz tão verídica quanto a própria realidade.

No histórico das literaturas, quase sempre autor e obra tornaram-se artífices representativos de determinados grupos. Essa função atribuída ao autor e a obra não se dá aleatoriamente, tendo em vista que a produção impelida pelo artista somente adquire existência a partir de elementos externos, inseridos em um contexto social e histórico, todavia do qual indiscutivelmente a obra faz parte. Assim, a obra não será apenas o reflexo dessa conjuntura, como também resultante do "influxo exercido pelos valores sociais, ideologias e sistema de comunicação, que nela se transmudam em conteúdo e forma" (CANDIDO, 1965, 35).

Para Moema Parente Augel, "a literatura possibilita pôr a descoberto os veios do inconsciente coletivo, veicula o que escapa à observação sociológica ou a documentação histórica, desvenda aspirações, fareja e antecipa as tensões subjacentes (1998, p. 19)". Neste sentido, é impossível negar a relação existente entre a literatura e a sociedade.

Marcelo Caetano, ao conjeturar sobre essa relação, assegura que:

O texto literário não é autônomo em relação ao ambiente histórico e cultural em que é produzido. Ele é um modo de projeção das questões e pontos de vista que configuram esse ambiente, sintoniza-se, em alguma medida, com a percepção própria do seu tempo. Noutros termos, a experiência literária não é exclusivamente estética, mas diz respeito a um certo modo de percepção que é histórico-cultural, implica uma escolha discursivo-ideológica daquele que escreve. (CAETANO, 2007, p. 3).

No caso da literatura guineense, percebe-se que os autores reunidos na compilação aqui cotejada se mostram preocupados com os assuntos de seu tempo, sobretudo, com a construção da nação. Esse anseio do artista de transformar a realidade através da obra se dá em função da relação existente entre autor, público e obra, denominada, por Antônio Candido, como tríade, ao mostrar que "a produção da obra 


\section{Revista do SELL}

v. 6 , no. 2

ISSN: $1983-3873$

literária deve inicialmente ser encarada como referência à posição social do escritor e à formação do público" (1967, p. 87).

A exploração e a subjugação do africano por parte do colonizador fez nascer em África um sentimento de revolta, resistência e desejo de libertação. Entretanto, para se libertar fazia-se imprescindível a conscientização das populações oprimidas. É nesse contexto que ganha relevo o trabalho do escritor engajado, isto é aquele que se coloca a serviço de uma determinada causa social. Com a intenção de elaborar um contra discurso e com o anseio de se distanciar da lógica colonialista, insere em suas obras um teor político e denunciativo, desenvolvendo, através dessas produções, uma relação de compromisso com a sociedade na qual está ambientado.

Nesse sentido, as literaturas africanas, de língua portuguesa, desenvolvidas durante os movimentos libertários e nos primeiros momentos da descolonização trazem em suas estruturas características que apontam para um fazer poético em que o autor se compromete e coloca em suas produções literárias, não apenas suas aspirações, como também os anseios de toda comunidade. Dessa perspectiva, o escritor, ao fazer de sua produção um brado denunciativo da opressão, torna as literaturas africanas um estandarte que unifica e transporta os ideais de nação livre a toda sociedade. Por isso é comum nessas literaturas a ocorrências de temas que demonstram a aversão ao colonizador, a exaltação à liberdade, a idealização de um futuro utópico e a confiança na revolução.

Situada na costa ocidental da África e inserida no âmbito dos cinco países africanos de língua portuguesa, a Guiné Bissau é um país que luta pela afirmação de identidade e reconhecimento, principalmente no campo político e literário. A posição geográfica da Guiné-Bissau acrescida da questão histórica é uma informação fundamental ao se pensar na produção literária do país. O fato de ter se tornado uma zona portuária e durante muito tempo ter sido colônia de exploração e não de assentamento fez com que o desenvolvimento cultural se desse tardiamente. As particularidades residem no fato de ainda no início do século $X X$, o reduzido número de intelectuais presentes nessas terras ou serem de Cabo-Verde e de outras localidades ou estarem a serviço do colonizador. Essa condição geográfica pode ter influenciado no fato da Guiné não ter conseguido se equiparar, tanto política quanto artisticamente, com os outros países egressos do colonialismo português, a saber Angola e Moçambique. 


\section{Revista do SELL}

v. 6 , no. 2

ISSN: $1983-3873$

A luta pela independência nesse país, além de provocar transformações no campo social e político implicou também em um rompimento com a literatura trazida pelo colonizador. A euforia que marcou os movimentos revolucionários despertou nos poetas o desejo de através dos elementos históricos e culturais, construírem uma identidade nacional, um processo que se deu concomitante ao desenvolvimento de uma poesia "genuinamente" guineense.

Desse modo, a literatura guineense passa a existir como espaço de formação de identidade e expressão de sentimento nacional, uma maneira de denunciar a realidade social, já que "a incontornável e dolorosa história de opressão transparece pelo tecido literário guineense, interligado às práticas de resistência e à arquitetação do futuro" (AUGEL, 2007, p. 21). Como uma recusa ao colonialismo, essa literatura, especificamente a poesia, surge inicialmente com um caráter de resistência ou combate uma literatura que "chama todo um povo para a luta pela existência nacional. Literatura de combate porque ela informa a consciência, dá-Ihes forma e contornos e abre-Ihes novas perspectivas" (FANON, 1979, p.270).

Assim, a publicação da antologia: Mantenhas para quem luta! (1977), representa a ruptura definitiva com a literatura colonial, revelando assim a existência de uma consciência nacional e o recente aparecimento do fazer literário na Guiné-Bissau. Apesar de tardia, essa literatura se mostra soberana, pois exibe diversas marcas próprias das histórias da Guiné-Bissau retratando suas lutas, sofrimentos, esperanças e liberdade.

Em síntese, o tema deste trabalho é de grande valor para o entendimento da clássica reflexão referente às relações entre a Literatura e a Sociedade, sobretudo no que tange à história, pois segundo Alfredo Bosi (2000), a poesia é por natureza inseparável da história. Ela [a poesia] tem o poder de revelar os desígnios dos opressores historicamente dominantes e dar impulso a novas maneiras de compreender a vida em sociedade, pois:

É nesse espaço que o poeta, cristalizador momentâneo dos sentimentos universais, funciona como um armador de símbolos, criando a camada conotativa-expressiva da linguagem organizando um sistema simbólico que apresenta a relação dialética entre a vida nacional e a sua expressão literária (CYNTRÃO, 2004, p.103).

Essa dialética é possível graças à capacidade criativa do poeta que busca, através da palavra e de sua criação, mostrar todos os movimentos existenciais. Embora possua um caráter intimista e subjetivo, o poema demonstra uma preocupação com o 


\section{Revista do SELL}

v. 6 , no. 2

ISSN: $1983-3873$

aspecto social, ou seja, pode ser visto como um código de representação do desejo coletivo, que procura traduzir a cultura e também os anseios de um povo.

É inegável o fato de que a literatura, enquanto um instrumento de interação social, o é dialeticamente, pois reflete a sociedade na qual ela se encontra invariavelmente inserida. Ambas, literatura e sociedade, estabelecem entre si uma relação necessária de interdependência, sendo possível observar em uma mesma obra tanto a natureza essencialmente estética da literatura, quanto a conformação fundamentalmente política da sociedade. Essa relação estreita da literatura com a sociedade a coloca no terreno da literatura engajada, que por princípio objetiva ser um espelho da sociedade para ela mesma, a fim de que esta possa tomar consciência de si própria, e assim consiga se superar continuamente.

O histórico da literatura produzida na Guiné- Bissau permite observar que desde a gênese não só do sistema literário, mas também do início da colonização sempre houve algum tipo de resistência por parte de alguém que ao fazer uma leitura do mundo resolveu se manifestar em favor de uma transformação, de um mundo mais justo e menos individualista. É nesse contexto de desejo de mudança de inconformismo com a situação estabelecida que se insere a poesia, tendo em vista que esta:

[...] resiste à falsa ordem, que a rigor a barbárie, o caos [...]. Resiste ao contínuo 'harmonioso' pelo descontinuo gritante; resiste ao descontínuo gritante pelo harmonioso. Resiste aferrando-se à memória viva do passado, e resiste imaginando uma nova ordem que se recorta no horizonte da utopia (BOSI, 2000, p. 169).

Alfredo Bosi, em seu livro Literatura e resistência, afirma que situações de crise e opressão desencadeiam forças profundas de resistência que, por sua vez, geram movimentos sociais. Os movimentos revolucionários, desenvolvidos na Guiné na década de 1960, fizeram com que a poesia lírica se tornasse mais politicamente engajada. Os poetas, conscientes de sua função perante a sociedade, se concentraram em produzir uma poesia que não apenas divulgasse as humilhações e violência políticas, mas também incitasse os leitores à ação.

Para o teórico a poesia moderna tem forte influência nas transformações sociais, mas a isenta de "criar materialmente o novo mundo e as relações sociais", já que essa empreitada está fora do alcance simbólico da poesia. Segundo o autor essa função caberia à revolução. 


\title{
Revista do SELL
}

v. 6 , no. 2

ISSN: $1983-3873$

\begin{abstract}
Um processo de agitação subversiva, diretamente saído da contradição entre o movimento das forças produtivas e o estado das relações sociais, processo implicativo de desordens consecutivas, mas sempre derivadas, ao nível das diversas superestruturas da vida social (CALVEZ, 1975, p. 232).
\end{abstract}

Dessa perspectiva, o termo revolução será relacionado neste trabalho a uma mudança radical não apenas na forma de pensar, mas também na forma de agir, baseado num projeto que tem como perspectiva "um outro mundo", que leva em conta a ideia de transformação tanto política, como social e ideológica. Isso coincide com a realidade vivenciada pelos poetas guineenses durante as lutas e após a independência.

Publicada em 1977, Mantenhas para quem luta é apontada em grande parte dos estudos guineenses como "o verdadeiro início de uma autêntica literatura do país (SPAREMBERGER, 2003, p. 163)". O fato ser considerada o marco literário do país não quer dizer que não tenha existido uma literatura anterior. $O$ que isso permite perceber é o valor da obra enquanto elemento de representação do país, uma vez que permeia em sua estrutura elementos que configuram a especificidade de sua produção, a saber, a alusão que alguns poemas fazem a fatos históricos, evidenciando a necessidade que o autor teve enquanto homem que representa o seu tempo e o seu povo.

Apesar de ainda não possuir uma tradição, essa primeira antologia, foi capaz de apresentar um esboço literário, ao mesmo tempo em que rebatia a outra necessidade, a de reerguer um país que embora livre ainda convivia com o atraso, aguda marca deixada pelos longos séculos de exploração e colonização portuguesa. Vale recordar aqui os estudos de Fanon, para quem a imposição colonialista:

[...] não se contenta com encerrar o povo nas suas redes, com esvaziar a cabeça do colonizado de qualquer forma e de qualquer conteúdo. Por uma espécie de perversão da lógica, orienta-se para o passado do povo oprimido, distorce-o, desfigura-o, e aniquila-o (FANON, 1979, p. 244).

Desse modo, Mantenhas para quem luta assume além da postura de resguardar e concomitantemente expor as particularidades pertencentes ao povo guineense, a atitude de evidenciar a violência e as desigualdades, impostas pelo colonizador, principais causas do tardio desenvolvimento do país. No que tange a revolução, a compilação poética supracitada, ao trazer poemas voltados para essa 


\section{Revista do SELL \\ v. 6 , no. 2 \\ ISSN: $1983-3873$}

temática, sobretudo, ao retratar a ação de vários intelectuais nos movimentos revolucionários, representa uma preocupação, em arquivar a história local e a história de importantes personalidades guineenses, dentre elas Amílcar Cabral, principal responsável pela revolução no país.

O espírito de "Unidade e Luta" empreendido por Amílcar Cabral teve reflexos diretos na produção literária da Guiné-Bissau, sobretudo nas antologias consideradas representantes não só de um período, mas também "testemunhos de uma voz coletiva" (MATA, apud, LARANJEIRA, 1995, p. 360). O desejo de continuar uma "unidade" estabelecida ainda nos movimentos revolucionários fez com que os poetas vissem na poesia e na produção de antologias uma forma de evitar a dispersão do povo e dos ideais, uma forte ameaça para aquele momento de se pensar e reerguer a nação.

Desse modo, numa tentativa não apenas de reunir, mas também instruir angariam produções que tragam em suas estruturas elementos que direcionem a um objetivo singular, atestando dessa forma o caráter pedagógico e documental das antologias. Segundo, Maria da Natividade Pires (1995, p. 323) o gênero antologia é uma forma de chamar a atenção para "autores e temas rejeitados, ou situações políticas e sociais intencionalmente escamoteadas, funcionando como provocação, acentuada pela condensação de nomes ou temas não aceites".

Para a pesquisadora, "as antologias têm uma função indispensável no conhecimento, conservação, revivificação e descoberta da literatura" (PIRES, 1995, p. 323). É dessa perspectiva que se observa a publicação das antologias poéticas guineense; além do desejo de reunir e agrupar nota-se também, como motivo para a produção das mesmas, uma finalidade anunciada pelos prefaciadores nas notas introdutórias, que é forjar um atestado da vitalidade da poesia da Guiné-Bissau.

Importante destacar que a antologia elegida como corpus deste trabalho, em suas particularidades, constitui uma maneira de conhecer e compreender a história, já que corrobora com a origem de uma forma de arquivamento. Sendo a primeira produção literária coletiva, nota-se que os poetas ainda se encontram fortemente vinculados aos acontecimentos anteriores à independência; essa compilação apresenta uma quantidade maior de poemas voltados à exaltação dos heróis, à resistência frente ao colonizador e à conquista da liberdade, ou seja, ainda se faz latente a aversão ao colonialismo.

Essa coletânea foi organizada conforme os critérios de valor e de representação de seus poemas. Concebendo valor não por serem escritos pelos melhores poetas ou por 


\section{Revista do SELL}

v. 6 , no. 2

ISSN: $1983-3873$

apresentarem poemas esteticamente mais bem estruturados, mas sim por serem produzidos por guineenses ávidos em se forjarem historicamente, ou seja, se autorepresentarem. Nesse sentido, percebe-se nesses textos a narração da história sob a perspectiva do fazer poético do nativo, o que evidencia a intenção deste em documentar para a posterioridade sua perspectiva sobre os acontecimentos de uma determinada época.

Essa concepção de antologia enquanto documento vai ao encontro da leitura que Elisa Helena Tonon faz de Derrida sobre o que é arquivo. Segundo a pesquisadora, a noção de arquivo derridariana, "não pressupõe hierarquia ou organização entre seus componentes, mas se constitui através do acúmulo, da estocagem que objetiva registrar, salvar, tornar certo material disponível para o futuro, como aposta, como penhor (TONON, 2008, p. 8)".

É a partir do conceito de antologia enquanto coletânea organizada situada em um tempo e espaço, que se pretende estudar neste tópico algumas poesias inseridas Mantenhas para quem luta publicada em 1977; obra que apesar de ter se esgotado cedo e não ter sido reeditada, até o momento, é considerada fundadora para a produção de uma ideia de literatura guineense.

A gênese das literaturas africanas de língua portuguesa, sobretudo, a da GuinéBissau, teve sua origem vinculada ao desejo de liberdade, de independência. A vontade de constituir-se nação foi o que contribuiu com a consolidação de temas discursivos que possibilitaram a configuração de um princípio literário. No entanto, vale ressaltar que, a existência de um conjunto de obras não é suficiente para se instituir o estatuto de sistema literário, pois, como sublinha Fátima Mendonça, a existência deste:

Só é assegurada por um reconhecimento posterior, pelos diversos elementos de recepção - crítica, reconhecimento nacional e internacional, prémios, edições nacionais e traduções - que, integrados no sistema de ensino - curricula, programas, manuais -, reproduzem conceitos e valores que, actuando em cadeia, convergem para a instituição do novo cânone, a literatura nacional. (MENDONÇA, 2008, p. 23).

Tais informações se fazem relevantes por ser este o momento de falar sobre o desejo dos agentes revolucionários da Guiné-Bissau de edificar uma literatura nacional, concomitante ao projeto de criação de uma nação, de uma identidade cultural. Dessa perspectiva, a antologia mencionada anteriormente funcionou como uma estratégia.. 


\section{Revista do SELL}

v. 6 , no. 2

ISSN: $1983-3873$

Ainda que na década de 1970 o conceito de identidade nacional não pudesse ser aplicado à realidade guineense, este foi crucial para reforçar os intentos dos homens empenhados na revolução.

Por tudo isso, buscou-se aqui o estudo dos primeiros escritos que já mostravam a capacidade artística e de auto representação dos guineenses. Essa primeira obra sistematizada, apesar de sua publicação constar a data de 1977, é composta por poemas que foram escritos nos primeiros momentos da agitação subversiva que movimentou toda a Guiné, ou seja, ainda na década de 60, conforme aponta a data grafada em alguns poemas compilados por Manuel Ferreira na Antologia poética da Guiné-Bissau (1990).

Ainda considerando a época em que essas poesias foram escritas, convém ponderar sobre o valor e a função dessa produção para o seu tempo. Através desses poemas é possível entender como os poetas colaboraram para a constituição de um espírito moderno na Guiné-Bissau, uma vez que, inicia aí um movimento de escrita simples, cotidiana e corriqueira, não muito atenta à forma, mas sim ao conteúdo, isto é, um movimento formado por escritores dotados de um olhar crítico, reflexivo e questionador.

Assim, entende-se que a escolha dos poemas contidos nessa compilação se deu através de um procedimento crítico de leitura e de escrita, no qual o organizadorautor, usando de sua autoridade e juízo, procurou apresentar poesias que priorizassem não a forma e o procedimento, mas sim o conteúdo, o que se justifica e se confirma nos textos aqui selecionados, sobretudo, nos quais se evidenciam referências temporais.

O fato da elaboração de uma antologia ser resultante da preferência do compilador leva a presumir que esta escolha, além de estar condicionada a um determinado momento, pode também estar condicionada a uma opção política. $\mathrm{O}$ que permite presumir que as características preponderantes das recolhas são, a quantidade e o significado dos poemas.

Deve-se ter em mente que uma antologia é consequência de seleção e, concomitantemente, exclusão, ou seja, o fato de uma coletânea ser composta por textos com a predominância de determinadas temáticas, não indica a inexistência de outros temas e produções. A apresentação pretensiosa dessa antologia como sendo um recorte, uma parcela da produção da época, traz à superfície o princípio geral de determinação deste trabalho, que é evidenciar o conflito existente entre a poesia e os mecanismos que reprimem o homem. 


\title{
Revista do SELL
}

v. 6 , no. 2

ISSN: $1983-3873$

Em "Poema de um assimilado", Agnelo Regalla, em uma leitura de mão dupla do processo de colonização, busca reconhecer e desmascarar a estratégia destrutiva usada pelo colonizador:

\author{
Fui levado \\ A conhecer a nona sinfonia \\ Beethoven e Mozart \\ Na música \\ Dante, Petrarca e Bocácio \\ Na literatura. \\ Fui levado a conhecer \\ A sua cultura... \\ Mas de ti, Mãe África? \\ Que conheço eu de ti? \\ Que conheço eu de ti? \\ A não ser o que me impingiram? \\ O tribalismo, o subdesenvolvimento, \\ E a fome e a miséria \\ Como complementos... \\ Não me falaram de ti \\ E dos teus filhos, Mãe África, \\ Esqueceram-se \\ De Samory e Abdelkader, \\ Cabral e Mondlane \\ Não me falaram da revolução[...] \\ Mas falaram-me dos Bandas e Honórios, \\ Dos que te esqueceram \\ E fugiram à doce melodia dos corás. (1977, p.15)
}

Através da composição estrutural do poema é possível evidenciar, gradativamente a tomada de consciência do eu-lírico. Em um processo de desassimilacão, o sujeito poético inicia o texto apresentando seu conhecimento sobre a cultura do colonizador. Ao findar essa apresentação com o verso "a sua cultura...", o sujeito poético, através do uso da reticência, deixa transparecer uma ideia de suspensão. Essa suspensão adquire sentido de renúncia, abandono, no uso do pronome possessivo "seu", no qual o eu-lírico expressa sua não integração àquela cultura.

O centro do texto marcado pela presença de interrogações indica um exame, uma revisão que o eu-lírico faz de sua consciência. Os versos "mas de ti Mãe África, / Que conheço eu de ti?", permitem que o eu-lírico, ao revisar sua condição alienada, perceba, através do fluxo de termos "tribalismo", "fome" e "miséria", imagens negativas de seu povo. Assim, no verso "como complementos..." o eu-lírico, através de uma ação suspensiva, assinaladas pelas reticências, põe fim a essa negatividade. As reticências 


\section{Revista do SELL}

v. 6 , no. 2

ISSN: $1983-3873$

nesses versos, indicam uma hesitação que denota a suspeição quanto às "verdades" ensinadas sobre a África.

Os versos seguintes do poema confirmam outra atitude do sujeito poético, principalmente quando este, em uma atitude que expressa um retorno às origens, ao dirigir-se novamente à "Mãe África", retoma gradativamente de "Cabral" à "revolução", ressaltando a insignificância dos "Bandas" e "Honórios", que permaneceram assimilados.

Por fim, ao encerrar o poema com o verso "E fugiram à doce melodia dos corás", o eu-lírico, em oposição aos que "fugiram" da luta pela libertação, propõe através da "melodia dos corás" como elemento já arraigado e pertencente à tradição africana, afirmando os valores não apenas da sua cultura, mas igualmente da sua identidade

A demonstração de consciência da opressão imposta pelo sistema colonial teve como marco inicial a greve empreendida pelos estivadores do porto do Pindjiguiti. Essa ação trouxe como consequências o massacre dos trabalhadores e o ingresso do PAIGC na luta que culminou na libertação do país. O número de poemas voltados para este episódio deixa entrever a significância do mesmo para a história e para os guineenses. Em "Aos que tombaram em Pindjiguiti”, Helder Tavares Proença, em uma retomada histórica, presta uma homenagem àqueles que demonstraram com a própria vida sua resistência e seu heroísmo. O uso da palavra Pindjiguiti no título do poema já aponta para a ambígua leitura aplicada ao mesmo. Isto se explica pelo fato de o termo dar nome a um lugar, um porto e simultaneamente fazer alusão a um acontecimento histórico:

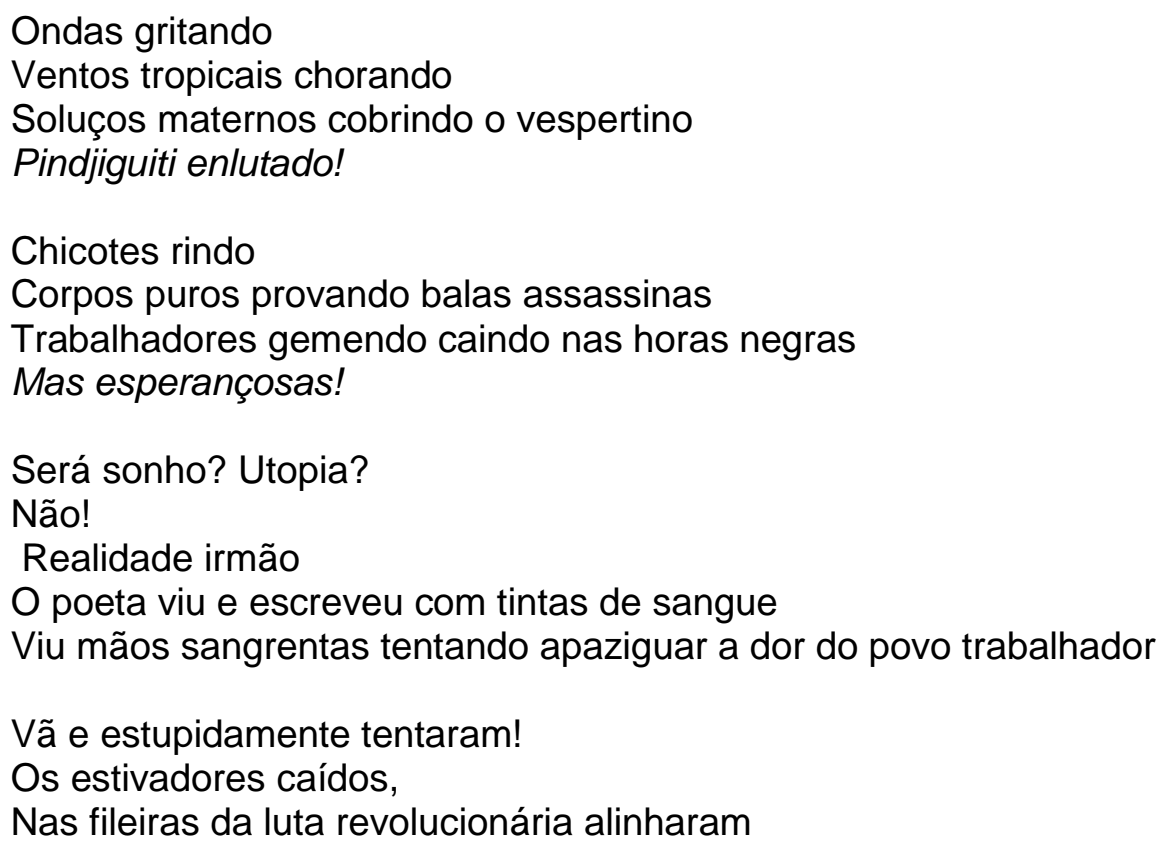




\section{Revista do SELL}

v. 6 , no. 2

ISSN: $1983-3873$

E seu sangue floriu no 24 de setembro

Secando as flores negras do imperialismo

Cobrindo o sol do colonialismo (1977, p. 47).

O poema possui como marca basilar o aspecto temporal; o sujeito, ao apresentar o fato histórico, faz uma oscilação entre o passado e o presente. As duas primeiras estrofes apresentam uma lírica situada no âmbito da memória, isto é, o eu-lírico retoma o acontecimento do passado como se estivesse no presente, o que se confirma no tempo dos verbos "gritando", "chorando", "rindo". O eu-lírico busca representar toda violência e dor, reconstruindo o cenário do episódio, que se tornou um campo de batalha (corpos, sangue, choro, grito). Nos versos "ondas gritando / ventos tropicais chorando" o sujeito poético personifica elementos naturais, de forma a representar o estado de espírito do ambiente.

A terceira estrofe mostra a transição do eu-lírico de um passado (um presente opressivo) a um futuro (que, dadas as circunstâncias históricas, também é passado) intermediado pela figura do poeta que enquanto líder "viu e escreveu [...] tentando apaziguar a dor", uma ação que àquele tempo pareceu utópica, mas que se concretizou historicamente, o que se ratifica nos últimos quatro versos do texto. Do segundo ao quarto verso da estrofe que encerra o poema tem-se a influência do massacre dos estivadores na conquista da independência, confirmando que o passado enquanto história reverbera no presente, ou seja, o massacre do Pindjiguiti simboliza o êxito da luta de libertação.

Essa forte marcação temporal, acrescida da história como pano de fundo no poema, denota uma oscilação por parte do eu-lírico entre a poesia lírica e a épica. Isto fica claro nos versos, "os estivadores caídos", I "nas fileiras da luta revolucionária alinharam" / "e seu sangue floriu no 24 de setembro" apontando dados temporais e a presença de sujeitos poéticos coletivizados, empenhados em cumprir a missão a eles atribuída.

A ideia de modificação de uma conjuntura social pressupõe uma transição, ou seja, a transformação de um determinado cenário em outro. A alteração panorâmica de uma sociedade, nos seus variados campos político, econômico, artístico, entre outros, demanda a participação ativa do povo, o que possibilita surgimento de um sentimento de comunhão. É a partir deste sentimento que surge a ideia de nação, "comunidade imaginada", na qual os indivíduos, mesmo não se conhecendo na totalidade se consideram pertencentes a um grupo específico. 


\section{Revista do SELL}

v. 6 , no. 2

ISSN: $1983-3873$

$\mathrm{Na}$ Guiné-Bissau, o sentimento de pertença a uma comunidade comum tornou possível a conquista da liberdade. É dessa perspectiva, isto é, da retomada desse sentimento, que os poetas, cientes de sua função e do poder de sua palavra, propõem, após a independência, a construção da nação.

A definição de povo enquanto conjunto de indivíduos duma localidade com história e tradições comuns aproxima-se do conceito de nação, proposto por Benedict Anderson, principalmente no que se refere ao sentimento de pertença a uma determinada comunidade. Os indivíduos, ao sentir-se pertencendo a um determinado grupo, além de falarem (na maioria das vezes) a mesma língua, também possuirão costumes e hábitos semelhantes, o que permite estabelecer uma identidade cultural.

É nesse eixo temático que se inscreve o poema "Aos que me querem amar", de Jorge Ampa Cumelerbo.

A todas elas e

E a eles também

Saberei apreciá-los

Em todo o seu ser

E Amplitude

Esses sim

E Direi Bom!...

Conheçam-me primeiro

Conhecendo vós mesmos a vossa origem

Saibam que eu existi há muito

Existo

E existirei

Para a continuidade da espécie

Para a continuidade da Luta!

Sejam vigilantes!...

Eu fui maltratado na pessoa dos jovens

Fui massacrado na carne dos velhos

Meninos e crianças bombardeados

Fui torturado nos corpos

Dos prisioneiros políticos

Fui mutilado nas canções

Danças e folclores populares

Vestiram-me outro nome

E deram-me à força (momentaneamente)

Outra cultura!

E sobrevivi

Porque sou o povo!

Se, me querem amar 


\section{Revista do SELL \\ v. 6 , no. 2 \\ ISSN: $1983-3873$}

Têm de sobreviver

Às intempérias

À vergonha e humilhações

Ao desenraizamento

Para que eu sobreviva

Porque sou o povo! (1977, p. 58-59)

Nos versos "conheçam-me primeiro / conhecendo vós mesmos a vossa origem", o eu-lírico se funde entre a primeira pessoa do singular e a segunda pessoa do plural. Verifica-se, neste jogo de inconstância identitária, o desejo do eu-lírico de forjar a identidade a partir do resgate da tradição, do retorno à "origem". Constata-se ainda que, ao movimentar-se entre os pronomes "vós" e "me", a discurso do sujeito poético se converte na voz do intelectual, o que permite atestar uma consciência do hibridismo identitário, fruto da história e da modernidade.

A estrofe seguinte mostra um eu-lírico que procura se apresentar historicamente através dos verbos "existi", "existo" e "existirei". A movimentação temporal presentes nesses verbos retoma uma característica basilar das literaturas emergentes, em que 0 passado possibilita um entendimento sobre o presente, e este, enquanto realidade opressiva, estimula a projeção de um futuro mais justo. Assim, os tempos expressos nos verbos demonstram a resistência do eu-lírico, sua "continuidade" através da "espécie" e da "luta".

$\mathrm{Na}$ quarta estrofe, faz-se evidente uma pluralização do eu-lírico. Os verbos em primeira pessoa do singular apresentam um "eu" dotado de individualidade que vai se dissolvendo nos determinados grupos e faixas etárias que compõem a sociedade. Esse processo culmina na coletivização do sujeito poético.

É possível evidenciar, ainda na estrofe, particularmente nos termos "bombardeados", "torturados", "prisioneiros políticos" e "corpos", versos que denotam a trágica e cruel experiência histórica do eu-lírico. A imagem que os europeus desenharam dos africanos, fez com que aqueles classificassem os nativos como selvagens que precisavam ser civilizados, precisavam de instrução. O verso, "vestiram-me outro nome", expressa não só uma tentativa de esmagamento cultural, mas também a supressão de identidade à qual o colonizado foi submetido ao ser batizado com outro nome, em outro credo.

Os sintagmas "e deram-me à força (momentaneamente) / outra cultura! / e sobrevivi", permitem observar como a resistência do autóctone, isto é do povo, sobreposta 


\section{Revista do SELL}

v. 6 , no. 2

ISSN: $1983-3873$

às determinações colonialistas, legitima uma impossibilidade de assimilação. $\mathrm{Na}$ progressão da estrofe ficam evidentes versos que exprimem a importância da sobrevivência do povo às intempéries / "à vergonha e humilhações" que acompanham o processo assimilacionista.

O fato de o colonizado acreditar, "momentaneamente", que na tentativa de assimilar-se "não é suficiente despedir-se de seu grupo, é preciso penetrar em outro (MEMMI, 1967, p.109)", faz com que autóctone acabe encontrando a "recusa do colonizador", isto a rejeição deste para com nativo. O que leva este a intuir que "tem de sobreviver", principalmente, "ao desenraizamento", para que "eu", o povo, a cultura, "sobreviva". O uso de primeira pessoa do singular aponta para um sujeito poético que, diante de sua individualização, acaba por atingir o universal, ou seja, é possível escutar na singularidade da voz do eu-lírico notas de uma voz coletiva, como bem o expressa o verso reiterado "porque sou o povo!".

Os escritores da Guiné, consciente de suas condições e de seu papel, tornaram o fazer poético um aliado na luta pela continuidade do espírito revolucionário. É dessa perspectiva que se destaca "escreverei mais um poema", de Helder Proença. Um texto no qual a temporalidade do verbo já aponta para a ideia de prosseguimento, constância, o que é reafirmado através do advérbio "mais" enquanto significador de quantidade.

Viverei mais um dia e escreverei mais um poema poema quebra as correntes e faz ceder as montanhas! Escreverei mais um poema enquanto as minhas células morrem e vivem em mim

Poema que desata as âncoras e solta os navios

Escreverei mais um poema Poema que alimenta a vitalidade

Ritmado pelo encadeamento do processo transformador.

Enquanto a minha decomposição

Do superior ao inferior não se realizar

Escreverei um poema que todas as crianças compreenderão

Enquanto há braços misticamente estendidos

Sobre as fortalezas da resignação

Escreverei um poema 


\title{
Revista do SELL
}

v. 6 , no. 2

ISSN: $1983-3873$

\begin{abstract}
Poema que será a arma dos oprimidos!
Poema que confunde com os anseios do povo

O MEU POEMA SERÁ A VOZ DO POVO
\end{abstract}

Enquanto a opressão que perturba o cérebro humano

Escreverei um poema - VITALIZADO PELA REVOLUÇÃO -

Poema que alimenta as condições

Para a transformação do velho em novo!

Mas se não consegui viver mais um dia

Se a minha decomposição vier a se realizar

A REVOLUÇÃO FALO-Á- POR MIM! (1977, p.51-52)

Neste poema, nota-se a presença de um eu-lírico, que consciente do poder da palavra, coloca-se como um vate, ou seja, um ser iluminado incumbido de orientar e guiar seu povo. Os verbos "viverei" e "escreverei" presentes nos dois primeiros versos do texto confirmam uma responsabilidade com o povo, no qual foi empenhado não só a palavra, mas também a vida do poeta. "Enquanto as minhas células morrem e vivem em mim" demonstram a condição sobre a qual a constância produtiva do bardo está submetida.

A ausência de rimas nas sete estrofes, proposital, sugere que o poeta deseja evitar uma prisão à forma. Isto vai ao encontro do desejo de liberdade expresso nos versos "poema que desata as ancoras" / "e solta os navios". Estes versos deixam explícito o caráter militante da poesia contra a opressão gestada com a chegada do colonizador.

No verso "poema que será arma dos oprimidos", o sujeito poético confere poder à palavra, já que seu texto, ao desvelar consciências, tornar-se-á arma de guerra. Os dois versos seguintes deixam evidente uma sutil coletivização do eu-lírico, o que permite constatar que o compromisso do vate coincide com "os anseios do povo", asseverando assim a participação ativa deste na luta pela libertação.

A presença dos pares antitéticos "morrem" e "vivem", "velho" e "novo" no início e no fim do texto, além de estabelecer um paralelo entre o fazer poético e a vida, denotam como vida e poema são um todo "vitalizado pela revolução".

O poema apresenta alguns sintagmas que, por serem grafados em maiúsculas, adquirem uma conotação de brado, ou seja, expressam um desejo do eu-lírico em se fazer ouvir e ser ouvido. A presença dos termos "poema", "povo", "revolução" e "mim", dentro desses versos apontam a sustentação da ideia de que as transformações de uma sociedade estão emaranhadas à relação existente entre autor, público e obra.

O uso dos verbos no tempo futuro expressa uma característica comum das literaturas africanas, que é a utopia, isto é, uma projeção ao futuro, representando o 


\section{Revista do SELL}

v. 6 , no. 2

ISSN: $1983-3873$

desejo de escapar e de modificar uma realidade opressiva. Ao encerrar o texto com o verso "A REVOLUÇÃO FALO-Á- POR MIM!", o eu-lírico confirma a ideia do futuro como lugar da concretização dos desejos e a revolução como porta de acesso às mudanças.

Em linhas gerais, o estudo da antologia, Mantenhas para quem luta, sobretudo dos poemas aqui comentados, permitiu perceber que a história da Guiné-Bissau, é recontada, embora em uma literatura ainda tímida, sob a perspectiva da afinidade existente entre arte e sociedade. Vale lembrar que é através do arranjo artístico que o escritor por meio de sua lide com a linguagem possibilita ao leitor o acesso aos acontecimentos de uma determinada época. Nesse sentido, a poesia funciona, aos seus leitores e personagens, como via de acesso ao conhecimento. Assim, a compilação aqui cotejada vai se validando. Ao tornar o sujeito lírico seu representante, o escritor, por meio de modelos fictícios, permite o apreender das necessidades de um determinado povo, ao mesmo tempo faz este povo conhecedor de sua própria condição social. Desse modo, a literatura permite novos olhares sobre a realidade. Daí a sua importância: tornar visível aquilo que não se pode ver sem os recursos ficcionais da obra de arte.

\section{Referências}

AUGEL, Moema Parente. O desafio do escombro: nação, identidades e pós-colonialismo na literatura da Guiné-Bissau. Rio de Janeiro: Garamond, 2007.

e Pesquisa (INEP), 1998.

A nova Literatura da Guiné-Bissau. Bissau: Instituto Nacional de Estudos

BOSI, Alfredo. O ser e o tempo da poesia. São Paulo: Companhia das letras, 2000.

CAETANO, Marcelo José. Itinerários Africanos: do colonial ao pós-colonial nas literaturas africanas de língua portuguesa. V. 4 Anos IV, № 2, 2007.

CALVEZ, Jean-Yves. O pensamento de Karl Marx. 2 Vols. Porto: Livraria Tavares Martins, 1975.

CANDIDO, Antonio. "O escritor e o público". In: Literatura e Sociedade. São Paulo: Editora Nacional, 1967.

Editora Nacional, 1965.

"A literatura e a vida social". In Literatura e Sociedade: São Paulo:

CYNTRÃO, Sylvia Helena. Como ler o texto poético: caminhos contemporâneos. Brasília: Plano, 2004. 


\section{Revista do SELL}

v. 6 , no. 2

ISSN: $1983-3873$

FANON, Frantz. Os condenados da terra. Tradução de José Laurenio de Melo. Rio de Janeiro: Civilização Brasileira, 1979.

MANTENHAS para quem luta! A nova poesia da Guiné-Bissau, Bissau: Conselho Nacional de Cultura, 1977.

MATA Inocência. A literatura da Guiné-Bissau. In: LARANJEIRA, Pires. Literaturas africanas de expressão portuguesa. Lisboa: Universidade Aberta, 1995. pp. 353-364.

MEMMI, Albert. Retrato do colonizado precedido do retrato do colonizador.Rio de Janeiro: Editora paz eTerra, 1967.

MENDONÇA, Fátima. Literaturas emergentes, identidades e cânone. In: Meneses, Maria Paula e Calafate Ribeiro, Margarida ( Orgs), Moçambique: das palavras escritas, Porto, Afrontamento, 2008. pp. 19-33.

PIRES, Maria da Natividade "Antologia", in Biblos, Enciclopédia Verbo das Literaturas de Língua Portuguesa, Vol. 1, Lisboa - São Paulo: Editora Verbo, pp. 322 - 323. 1995

SPAREMBERGER, Alfeu. A singularidade da literatura guineense no contexto das literaturas de língua portuguesa. Universidade de São Paulo: Tese de doutorado. 2003.

TONON, E. H. A poesia brasileira em suas antologias. In: I Simpósio Mundial de Estudos de Língua Portuguesa, 2008, São Paulo: Anais do I Simelp, 2008. 